Research

\title{
Factors Influencing Farmers Participation in the Vaccination Program against Anthrax in Bogor District, Indonesia
}

\author{
Chaerul Basri' ${ }^{{ }^{*}}$ A. S. Dwidzuriputra², Etih Sudarnika ${ }^{1}$ \\ ${ }^{1}$ Department of Animal Disease and Veterinary Public Health, Faculty of Veterinary Medicine, \\ IPB University, Bogor, Indonesia \\ ${ }^{2}$ Undergraduate Program, Faculty of Veterinary Medicine, \\ IPB University, Bogor, Indonesia \\ *Corresponding author: chaerulbasri@gmail.com \\ Submitted 7 November 2019, Accepted 22 December 2019
}

\begin{abstract}
Bogor District is one of the endemic areas of anthrax cases in Indonesia. The mass vaccination campaign on livestock including goats and sheep needs to be done to prevent the spread of the disease. The willingness of farmers to participate is the main key to the success of this vaccination campaign. This study aimed to identify the factors that influence the willingness of goat and sheep farmers to participate in vaccination programs against anthrax in their farms. A total of 60 goat and sheep farmers were randomly selected from 3 villages located in the region with the highest incidence of cases in Babakan Madang Subdistrict. Data was collected through direct interviews using a structured questionnaire. Analysis to determine risk factors was carried out by chi square test and continued by calculating the value of relative risk (RR) to measure the magnitude of the influence of these factors. The results showed that the factors that influenced the farmers to be willing to participate in the anthrax vaccination program were history that had been directly counseled with $\mathrm{RR}$ values $2,844(95 \% \mathrm{Cl}=1,547-5,288)$ and history of having constrained to vaccinate their livestock with $R R$ values $1,960(95 \% \mathrm{Cl}=1,203-3,193)$. Based on these findings it is recommended to increase farmer participation in mass vaccination programs against anthrax can be done through increasing communication, information and education activities and minimizing constraints for farmers to vaccinate their livestock.
\end{abstract}

Keywords: anthrax, participation, vaccination, farmer, sheep, Bogor

\begin{abstract}
ABSTRAK
Kabupaten Bogor adalah salah satu daerah endemis kasus antraks di Indonesia. Kampanye vaksinasi massal pada ternak termasuk kambing dan domba perlu dilakukan untuk mencegah penyebaran penyakit. Kesediaan peternak untuk berpartisipasi merupakan kunci utama keberhasilan kampanye vaksinasi ini. Penelitian ini bertujuan untuk mengidentifikasi faktor-faktor yang mempengaruhi kesediaan peternak kambing dan domba untuk berpartisipasi dalam program vaksinasi massal antraks. Sebanyak 60 petenak kambing dan domba dipilih secara acak dari 3 desa yang terletak di wilayah dengan insiden kasus tertinggi di Kecamatan Babakan Madang. Data dikumpulkan melalui wawancara langsung menggunakan kuesioner terstruktur. Analisis untuk menentukan faktor risiko dilakukan dengan uji chi-square dan dilanjutkan dengan menghitung nilai risiko relatif (RR) untuk mengukur besarnya pengaruh faktorfaktor tersebut. Hasil penelitian menunjukkan bahwa faktor-faktor yang mempengaruhi peternak untuk bersedia berpartisipasi dalam program vaksinasi massal antraks adalah riwayat pernah mendapatkan penyuluhan secara langsung dengan nilai RR 2.844 (TK 95\% = 1.547-5.288) dan riwayat memiliki kendala untuk memvaksinasi ternak mereka dengan nilai RR 1.960 (TK $95 \%=1.203$ - 3.193). Berdasarkan temuan ini, direkomendasikan untuk meningkatkan partisipasi peternak dalam program vaksinasi massal antraks dapat dilakukan melalui peningkatan kegiatan komunikasi, informasi dan edukasi serta meminimalkan kendala bagi peternak untuk memvaksinasi ternak mereka.
\end{abstract}

Kata kunci: antraks, partisipasi, vaksinasi, peternak, domba, Bogor 


\section{INTRODUCTION}

Anthrax is a zoonotic disease caused by the bacterium Bacillus anthracis. These gram-positive bacteria have an ability to form spores when exposed to oxygen (Department of Agriculture 2003). Diseases with other names are Spleenitis, Miltbrand, Miltvuur, Splenic Fever, Malignant Pustule, Malignant Edema, Rag Picker Disease, Charbon, Malignant Carbuncle, Hematic Anthrax, Bacterial Anthrax, and Woolsorters Disease are one of the major zoonoses in the world (Ministry of Health 2002, Basri and Kiptiyah 2010). Anthrax is one of the most dangerous biological weapons in the world because anthrax has a high rate of death, illness, and causing high panic to humans (Klinman and Tross 2008).

Cases of anthrax were reported to occur almost all over the world both in developed and developing countries such as Britain, France, Germany, Siberia, Iran, Tibet, China, India, Arabia, South America, Africa, Australia, Japan, and Indonesia. The incidence of anthrax in Indonesia was first reported in 1832 in Tirawuta and Mowewe Districts, Kolaka Regency, Southeast Sulawesi. An anthrax case occurred in 2005 in Citaringgul Village, Babakan Madang Subdistrict, Bogor District and resulted in the death of 6 residents (Noor 2001; Natalia and Adji 2006).

Various efforts have been made by the Bogor District Fisheries and Livestock Service to prevent the recurrence or spread of cases of anthrax, including mass vaccination and extension programs in endemic areas. Vaccination is the act of administering a vaccine into the body of an animal or human to prevent diseases caused by bacteria and viruses (Soeripto 2002). Anthrax vaccination efforts have not given optimal results due to the side effects of the live spore vaccine used and the low awareness of the community in vaccinating (Hardjoutomo et al. 1993, Leppla et al. 2002). The government needs to make efforts to increase public awareness to participate in the vaccination program organized by the government in an effort to prevent the spread of anthrax.

This study aimed to determine the factors influencing the willingness of goat and sheep farmers in Babakan Madang Sub-District, Bogor District to participate to anthrax mass vaccination programs organized by the government. The benefits of this research are expected to provide information to the Bogor District government to increase the participation of farmers in the anthrax mass vaccination program carried out in $\mathrm{Ba}$ bakan Madang Sub-district, Bogor District.

\section{MATERIAL AND METHODS}

This research was conducted in the Babakan Madang Sub-district, Bogor District. Data were processed and analyzed at the Epidemiology Laboratory, Faculty of Veterinary Medicine, IPB University. The study was conducted using a crosssectional study design. The study population was goat or sheep farmers in Babakan Madang Subdistrict. This sub-district was one of the anthrax endemic areas in Bogor District. Samples of farmers were selected using a multistage random sampling technique using a list of farmers belonging to the Fisheries and Livestock Service Office. Three villages out of a total of 9 villages in Babakan Madang Subdistrict were chosen randomly. From each village, each of them was selected in order 2 neighborhood associations (rukun warga/RW), 2 Sub-neighborhood associations (rukun tetangga/RT), and 5 farmers. The total number of respondents was 60 farmers.

Data were collected by direct interview using a questionnaire. The questionnaire consisted of questions including the characteristics of the farmer, caring management, health management, history of anthrax events and access to information of the farmer about anthrax.

Data were analyzed by chi-square test to determine the relationship and the calculation of Relative Risk (RR) values to measure the degree of association between risk factors for farmers' willingness to participate in mass vaccination programs.

\section{RESULTS}

The association between some risk factors and farmers' willingness to participate on anthrax mass vaccination programs have been analyzed. The for the risk factors related with the characteristics of farmers are shown in Table 1, for the risk factor related with anthrax case history can be seen in Table 2, for the risk factors related with health management can be seen in Table 3 and for the risk factors related with accesses to information are shown in Table 4. 
Table 1 The association between farmer characteristics and farmers' willingness to participate in the anthrax mass vaccination program

\begin{tabular}{|c|c|c|c|c|c|c|c|}
\hline \multirow{3}{*}{ No } & \multirow{3}{*}{ Variable } & \multicolumn{4}{|c|}{ Willingness to participate } & \multirow{3}{*}{ RR } & \multirow{3}{*}{$95 \% \mathrm{Cl}$} \\
\hline & & \multicolumn{2}{|c|}{ Yes } & \multicolumn{2}{|c|}{ No } & & \\
\hline & & $\mathrm{n}$ & $\%$ & $\mathrm{n}$ & $\%$ & & \\
\hline \multirow[t]{3}{*}{1} & Education & & & & & & \\
\hline & - Maximum elementary school graduates & 33 & 57.9 & 24 & 42.1 & 1.737 & $0.345-8.737$ \\
\hline & - Minimum junior high school graduates & 1 & 33.3 & 2 & 67.7 & & \\
\hline \multirow[t]{3}{*}{2} & Number of animals & & & & & & \\
\hline & - More than 5 heads & 16 & 66.7 & 8 & 33.3 & 1.333 & $0.865-2.054$ \\
\hline & - Less than 5 heads & 18 & 50 & 18 & 50 & & \\
\hline \multirow[t]{3}{*}{3} & The purpose of raising animals & & & & & & \\
\hline & - For sale & 33 & 57.9 & 24 & 42.1 & 1.737 & $0.345-8.737$ \\
\hline & - Not for sale & 1 & 33.3 & 2 & 66.7 & & \\
\hline \multirow[t]{3}{*}{4} & The function of raising animal & & & & & & \\
\hline & - Main income & 2 & 50 & 2 & 50 & 1.143 & $0.418-3.125$ \\
\hline & - Secondary income & 32 & 57.1 & 24 & 42.9 & & \\
\hline Note: & $\begin{array}{ll}\mathrm{n} & : \text { sample size } \\
\mathrm{RR} & : \text { relative risk } \\
95 \% \mathrm{Cl} & : 95 \% \text { confidence interval }\end{array}$ & & & & & & \\
\hline
\end{tabular}

\section{DISCUSSION}

Based on data analysis, it is known that the characteristics of farmers include education, number of animal, the purpose of raising farm and farming functions are not related to the willingness of farmers to participate in anthrax vaccination programs. Farmer education does not affect the willingness of farmers to take part in vaccination programs because most (95\%) farmers have low education (elementary school). This result does not in accordance with the opinion of Kheiri et al. (2011) that education would increase knowledge and produce better attitudes. This is also supported by the results of anthrax KAP research which states that there was a significant association between the level of knowledge related to anthrax disease and the level of education of cattle farmers in Banaran Village, Galur Sub-district, Kulon Progo District (Alfaruqi et al. 2018). This result is also in accordance with the results of the FKH IPB study (2005) that the condition of farmers' education had an influence on the ability to absorb various information relevant to their livestock business activities, especially with regard to handling livestock businesses.

Most of farmers are known to only have less than 5 goats or sheep. Although the amount is small, these animals were intended to be sold as additional income for the families of farmers. The majority of farmers claimed to raise farm only to get additional income, not as the main income for their families. Small-scale farms usually do not have an awareness of the importance of vaccination to pre- vent disease so that the number of animal, the purpose and function of farm raising did not affect the willingness of farmers to participate in anthrax vaccination programs.

Although living in endemic areas of anthrax, only a small proportion of farmers claimed their animals or family members have been infected with anthrax. History of anthrax cases in this region did not affect the level of willingness of farmers to take anthrax vaccination programs. This may be caused by farmers who do not have good knowledge about the important role of vaccination in preventing anthrax cases. This is supported by Wahyuni and Basuno (2006) that the main obstacle in the implementation of anthrax vaccination programs in the field was the limited knowledge of farmers about the importance of vaccination for the prevention of anthrax.

Almost a half of the farmers stated that their animal had been sick and had died while raising livestock. Based on the diagnosis by the official of the service that caused the illness or death of their animals, it was not caused by anthrax. Animal and human health workers in this area have taken good control measures of each cases so that the spread and impact of the disease can be controlled. History of cases of illness or death of animals did not cause farmers to worry about anthrax cases. This causes the history of cases of illness or death of animals did not related to the willingness of farmers to participate in anthrax vaccination programs.

Disseminating information about vaccination is a very important activity in an effort to increase farmer participation in vaccination programs. According 
32 | Basri et al.

Table 2 Relationship between history of anthrax events and farmers' willingness to participate in anthrax vaccination programs

\begin{tabular}{|c|c|c|c|c|c|c|c|}
\hline \multirow{3}{*}{ No } & \multirow{3}{*}{ Variable } & \multicolumn{4}{|c|}{ Willingness to participate } & \multirow{3}{*}{$\mathrm{RR}$} & \multirow{3}{*}{$95 \% \mathrm{Cl}$} \\
\hline & & \multicolumn{2}{|c|}{ Yes } & \multicolumn{2}{|c|}{ No } & & \\
\hline & & $\mathrm{n}$ & $\%$ & $\mathrm{n}$ & $\%$ & & \\
\hline \multirow[t]{3}{*}{1} & $\begin{array}{l}\text { History of having a family that has been } \\
\text { infected with anthrax }\end{array}$ & & & & & & \\
\hline & - Yes & 0 & 0 & 2 & 100 & - & - \\
\hline & $-\quad$ No & 34 & 58.6 & 24 & 41.4 & & \\
\hline \multirow[t]{3}{*}{2} & $\begin{array}{l}\text { History of having animals that has been } \\
\text { infected with anthrax }\end{array}$ & & & & & & \\
\hline & - Yes & 3 & 75 & 1 & 25 & 1.355 & $0.734-2.5$ \\
\hline & $-\quad$ No & 31 & 55.4 & 25 & 44.6 & & \\
\hline
\end{tabular}

Note: $\mathrm{n}$ : sample size

$\mathrm{RR}$ : relative risk

95\% Cl : 95\% confidence interval

Table 3 The association between health management and farmers' willingness to participate in anthrax mass vaccination programs

\begin{tabular}{|c|c|c|c|c|c|c|c|}
\hline \multirow{3}{*}{ No } & \multirow{3}{*}{ Variable } & \multicolumn{4}{|c|}{ Willingness to participate } & \multirow{3}{*}{$\mathrm{RR}$} & \multirow{3}{*}{$95 \% \mathrm{Cl}$} \\
\hline & & \multicolumn{2}{|c|}{ Yes } & \multicolumn{2}{|c|}{ No } & & \\
\hline & & $\mathrm{n}$ & $\%$ & $\mathrm{n}$ & $\%$ & & \\
\hline \multirow[t]{3}{*}{1} & History of having sick animals & & & & & & \\
\hline & - Yes & 18 & 60 & 12 & 40 & \multirow{2}{*}{1.125} & \multirow{2}{*}{$0.721-1.754$} \\
\hline & No & 16 & 53.3 & 14 & 46.7 & & \\
\hline \multirow[t]{3}{*}{2} & History of having dead animals & & & & & & \\
\hline & - Yes & 16 & 61.5 & 10 & 48.5 & \multirow{2}{*}{1.162} & \multirow{2}{*}{$0.749-1.803$} \\
\hline & $-\quad$ No & 18 & 52.9 & 16 & 47.1 & & \\
\hline \multirow[t]{3}{*}{3} & $\begin{array}{l}\text { History had problems joining the } \\
\text { vaccination program }\end{array}$ & & & & & & \\
\hline & $-\quad$ No & 12 & 38.7 & 19 & 61.3 & & \\
\hline & - Yes & 22 & 75.9 & 7 & 24.1 & $1.960 *$ & $1.203-3.193$ \\
\hline \multirow[t]{3}{*}{4} & $\begin{array}{l}\text { Worried that animals will die from } \\
\text { being vaccinated }\end{array}$ & & & & & & \\
\hline & $-\quad$ No & 13 & 44.8 & 16 & 55.2 & 1.511 & $0.943-2.421$ \\
\hline & - Yes & 21 & 67.7 & 10 & 42.3 & & \\
\hline
\end{tabular}

$$
\begin{array}{lll}
\text { Note: } & \mathrm{n} & : \text { sample size } \\
& \mathrm{RR} & : \text { relative risk } \\
95 \% \mathrm{Cl} & : 95 \% \text { confidence interval } \\
& * & : \text { Significant at the } 5 \% \text { test level }(\alpha=0.05)
\end{array}
$$

to Wahyuni and Basuno (2006) farmers really needed to be programmed with education about anthrax disease so that farmers had knowledge of the the dangers of anthrax. For this purpose, the most effective strategies are needed to be discussed in a participatory manner with farmers. The majority of farmers mention leaflets, direct extension and mass media as the main sources of information about anthrax. Although all the three communication tools played a very important role, the direct extension factor significantly increases the willingness of farmers to participate in anthrax vaccination programs. Direct extension has several advantages including direct face-to-face between extension workers and farmers so that there can be two-way interaction.

Direct extension allows farmers to directly consult vaccination problems in accordance with the conditions of the farmer to the extension agent. This is also supported by Notoatmodjo's (2003) statement that a person's knowledge could be increased through training or extension. This is also in line with the opinion of Sudrajat (2012) that health education influenced knowledge and attitudes about preventing anthrax in cattle farmers in Brojol Miri Village, Sragen District. The effectiveness of extension to increase community knowledge was 
Table 4 The association of access to information on farmers' willingness to participate in anthrax mass vaccination programs

\begin{tabular}{|c|c|c|c|c|c|c|c|}
\hline \multirow{3}{*}{ No } & \multirow{3}{*}{ Variable } & \multicolumn{4}{|c|}{ Willingness to participate } & \multirow{3}{*}{$\mathrm{RR}$} & \multirow{3}{*}{$95 \% \mathrm{Cl}$} \\
\hline & & \multicolumn{2}{|c|}{ Yes } & \multicolumn{2}{|c|}{ No } & & \\
\hline & & $\mathrm{n}$ & $\%$ & $\mathrm{n}$ & $\%$ & & \\
\hline \multirow[t]{3}{*}{1} & Mass media & & & & & & \\
\hline & - Yes & 15 & 65.2 & 8 & 34.8 & 1.270 & $0.824-1.928$ \\
\hline & $-\quad$ No & 19 & 51.4 & 18 & 48.6 & & \\
\hline \multirow[t]{3}{*}{2} & Leaflet & & & & & & \\
\hline & - Yes & 34 & 58.6 & 24 & 41.4 & - & - \\
\hline & $-\quad$ No & 0 & 0 & 2 & 100 & & \\
\hline \multirow[t]{3}{*}{3} & Direct extension & & & & & & \\
\hline & - Yes & 26 & 81.2 & 6 & 18.8 & $2.844^{*}$ & $1.547-5.288$ \\
\hline & $-\quad$ No & 8 & 28.6 & 20 & 71.4 & & \\
\hline
\end{tabular}

$\begin{array}{lll}\text { Note }: & \mathrm{n} & : \text { sample size } \\ \mathrm{RR} & : \text { relative risk } \\ 95 \% \mathrm{Cl} & : 95 \% \text { confidence interval } \\ * & : \text { Significant at the } 5 \% \text { test level }(\alpha=0.05)\end{array}$

also mentioned in research conducted by Suartha et al. (2011) which stated that ongoing extension could effectively increase understanding of bird flu in rural communities in Bali.

\section{CONCLUSION}

Risk factors that influence sheep and goat farmers in Bogor District to be willing to participate in the anthrax mass vaccination program include getting information about anthrax through direct extension with a relative risk value of $2,844(95 \% \mathrm{Cl}=$ $1,547-5,288$ ) and have a history of ever having problems to participate in the anthrax mass vaccination program has a relative risk value of $1,960(95 \% \mathrm{Cl}=$ 1,203-3,193).

\section{ACKNOWLEDGEMENTS}

We are grateful to the farmers, the Fisheries and Livestock Services of Bogor District for their help in providing the staffs and data for this study.

"All authors declare that there are no conflicts of interest".

\section{REFERENCES}

Al Faruki, M.F.B., Rizki, R.L.P., Rustamadji, dan Wahab, A., 2018. Tingkat Pengetahuan, Sikap dan Perilaku Peternak Sapi terhadap Penyakit Antraks di Desa Banaran Kecamatan Galur Kabupaten
Kulon Progo. [Skripsi]. Universitas Gadjah Mada.

Basri C, Kiptyah NM. 2010. Memegang Hewan Rentan dan Menangani Produknya Berisiko Besar Tertular Antraks Kulit di Daerah Endemis. Jurnal Veteriner 11 (4): 226-231.

Departemen Kesehatan Republik Indonesia. 2002. Pedoman dan Protap Penatalaksanaan kasus Antraks di Indonesia. Jakarta.

Departemen Kesehatan. 2003. Pedoman Tata Laksana Kasus dan Pemeriksaan Laboratorium Penyakit Antraks di Rumah Sakit. Dirjen Pemberantasan Penyakit Menular dan Penyehatan Lingkungan. Departemen Kesehatan RI.

Gindo MS. 2002. Laporan Pelaksanaan Penelitian Studi Lingkungan Penyebab Berulangnya Wabah Anthrax di Kabupaten Bogor, Jawa Barat. Pusat Penelitian dan Pengembangan Ekologi Kesehatan, Badan Penelitian dan Pengembangan Kesehatan, Departemen Kesehatan Republik Indonesia: Jakarta.

Harahap SAN. 2012. Higiene Pekerja Kantin di dalam Kampus Institut Pertanian Bogor Dramaga, Bogor. [skripsi]. Bogor: Institut Pertanian Bogor.

Hardjoutomo S, M.B. Poerwadikarta. B. E. Patten, dan K Barkah. 1993. The application of ELISA to monitor the vaccinal response of anthrax vaccinated ruminants. Penyakit Hewan Ed. Khusus 46A. 25: 7-10.

Kheiri M, Sahebalzamani M, Jahantigh M. 2011. The study of education effect on knowledge and attitudes toward electroconclusive theraphy among iranian nurse and patient's relatives in a psychiatric hospital 2009-2010. Soc Behav Sci 30: 256-260. 
Klinman DM, Tross D. 2008. Improvements in the Prevention and Treatment of Anthrax Infection. USA: cancer and inflamation program, National Cancer Institute. Procedia in vaccinology I (2009): 89-96.

Kurniawati $\mathrm{Y}$, Kusnoputranto H, Simanjuntak G. 2004. Dinamika Penularan dan Faktor-Faktor yang Berhubungan dengan Kejadian Penyakit Anthrax pada Manusia di Wilayah Kecamatan Babakan Madang, Kabupaten Bogor, Jawa Barat Tahun 2004. Lokakarya Nasional penyakit Zoonosis. Universitas Sriwijaya Palembang.

Leppla S H, J B Robbins, R Schineerson dan J Shiloach. 2002. Development of an Improved Vaccine for Antrhrax. J. Clin. Invest. 110 (2): 141-144.

Naipospos TSP. 2005. Beternak di Daerah Endemis Antraks Perlunya Komunikasi Resiko. [terhubung berkala]. Kompas. Sabtu, 5 Maret 2005.

Natalia L dan Adji S R. 2006. Pengendalian penyakit antraks: diagnosis, vaksinasi, dan investigasi. Wartazoa 16 (4):198-205.

Noor S M, Darminto, dan Hardjoutomo S. 2001. Kasus antraks pada manusia dan hewan di Bogor pada awal tahun 2001. Wartazoa 11(2): 8-14.

Soejoedono RR. 2005. Sejarah Antraks. [terhubung berkala]. www.poultryindonesia.com. [11 Januari 2012].
Suartha, N., Widana, K., Anthara, M.S., Wirata, W., Sukada, M. and Mahardika, G.N.K., 2011. Efektivitas penyuluhan terhadap pemahaman Flu Burung. Majalah Ilmiah Peternakan 14: 22-27.

Sudrajat, H.S., 2012. Pengaruh Pendidikan Kesehatan Tentang Pencegahan Penyakit Antraks Terhadap Pengetahuan dan Sikap Peternak Sapi di Desa Brojol Miri Sragen. [Skripsi]. Universitas Muhammadiyah Surakarta.

Tim Antraks FKH IPB. 2005. Pengawasan Antraks di Kabupaten Bogor Jawa Barat. Laporan Kegiatan kerjasama Dinas Peternakan Propinsi Jawa Barat.

Soeripto. 2002. Pendekatan konsep kesehatan hewan melalui vaksinasi. Jurnal Penelitian dan Pengembangan Pertanian 21:48-55.

Wahyuni S dan Basuno E. 2006. Penanggulangan Penyakit Antraks Secara Partisipatif. Seminar Nasional Teknologi Peternakan dan Veteriner 2006. Pusat Analisi Sosial Ekonomi dan Kebijakan Pertanian.

Wicaksono A. 2012. Faktor-Faktor yang Mempengaruhi Praktik Biosekuriti Pedagang pada Pasar Burung di Wilayah DKI Jakarta Terkait Avian Influenza. [Tesis]. Bogor: Institut Pertanian Bogor. 